\title{
Different responses of Ross River virus to climate variability between coastline and inland cities in Queensland, Australia
}

\section{S Tong, W Hu}

See end of article for authors' affiliations .....................

Correspondence to: Dr S Tong, Centre for Public Health Research, Queensland University of Technology, Kelvin Grove, Queensland 4059, Australia;

s.tong@qut.edu.au

Accepted 10 April 2002

\begin{abstract}
Aims: To examine the potential impact of climate variability on the transmission of Ross River virus (RRv) infection, and to assess the difference in the potential predictors of RRv incidence in coastline and inland regions, Queensland, Australia.

Methods: Information on the RRv cases notified between 1985 to 1996 was obtained from the Queensland Department of Health. Climate and population data were supplied by the Australian Bureau of Meteorology and the Australia Bureau of Statistics, respectively. The function of cross correlations was used to compute a series of correlations between climate variables (rainfall, maximum temperature, minimum temperature, relative humidity, and high tide) and the monthly incidence of RRv disease over a range of time lags. Time series Poisson regression models were performed to adjust for the autocorrelations of the monthly incidences of RRv disease and the confounding effects of seasonality, the case notification time, and population sizes.

Results: The cross correlation function shows rainfall, maximum temperature, minimum temperature, and relative humidity at a lag of 1-2 months and high tide in the current month were significantly associated with the monthly incidence of RRv in the coastline region. Relative humidity and rainfall at a lag of two months was also significantly associated with the monthly incidence of RRv in the inland region. The results of Poisson regressive models show that the incidence of RRv disease was significantly associated with rainfall, maximum temperature, minimum temperature, relative humidity, and high tide in the coastline region, and with rainfall and relative humidity in the inland region. There was a significant interaction between climate variables and locality in RRv transmission.

Conclusions: Climate variability may have played a significant role in the transmission of RRv. There appeared to be different responses of RRv to climate variability between coastline and inland cities in Queensland, Australia. Maximum temperature appeared to exhibit a greater impact on the RRv transmission in coastline than in inland cities. Minimum temperature and relative humidity at $3 \mathrm{pm}$ inland seemed to affect the RRv transmission more than at the coastline. However, the relation between climate variables and RRv needs to be viewed within a wider context of other social and environmental factors, and further research is needed.
\end{abstract}

R oss River virus (RRv) is the commonest and most widespread arbovirus infection in Australia. ${ }^{12}$ It was first identified as epidemic ployarthritis in the Murrumibidgee River area of New South Wales in $1928 .^{3}$ The causative agent was recognised as a mosquito borne alphavirus in $1960 .^{4}$ A virus was isolated from Aedes vigilax mosquitoes collected around Ross River near Townsville in 1963 and given the name Ross River virus. ${ }^{5}$

RRv is characterised by arthritis, rash, and constitutional symptoms such as fever, fatigue, and myalgia. ${ }^{6} \mathrm{R}$ v is recorded as geographically scattered cases throughout the year, but with the preponderance of cases in the period of January to May, particularly in the tropics. ${ }^{7}$ It is a debilitating disease. Symptoms in some cases can last months or years.

Over the past 10 years (1991-2000), a total of more than 53347 laboratory confirmed cases of RRv infection were reported in Australia; the majority of cases were notified in Queensland. ${ }^{8}$ A number of studies have examined the relation between climate variation and arboviral disease. ${ }^{9-12}$ Several models have been developed to assess the potential impact of such future climatic changes on health. ${ }^{11}$ The incidence of RRv has been linked to climatic factors, particularly rainfall, high tide, and temperature. ${ }^{10}{ }^{12}$ However, the quantitative relation between climate variation and the transmission of arboviruses remains to be determined.
Time series methodology has a long history of application in econometrics, particularly in the domain of forecasting. Recently, it has been used extensively to study the effects of environmental exposures (for example, air pollution on mortality and morbidity). ${ }^{13-16}$ The Poisson regression model is commonly used for analysing discrete data. The underlying assumption is that the number of events follows a Poisson distribution. ${ }^{17-20}$

This paper aims to examine the potential impact of climate variability on the transmission of RRv infection using the time series Poisson regression models, and to assess the difference in the potential predictors of the $\mathrm{RRv}$ incidence between coastline and inland regions, Queensland, Australia.

\section{METHODS}

Queensland is the second largest state (behind Western Australia) and it has the largest habitable area in Australia. It covers approximately 1727000 square km, with $7400 \mathrm{~km}$ of mainland coasting (9800 km including islands). Lying generally between $10^{\circ}$ and $29^{\circ}$ south of the equator, it ranges from

Abbreviations: EIP, extrinsic incubation period; RRv, Ross River virus 


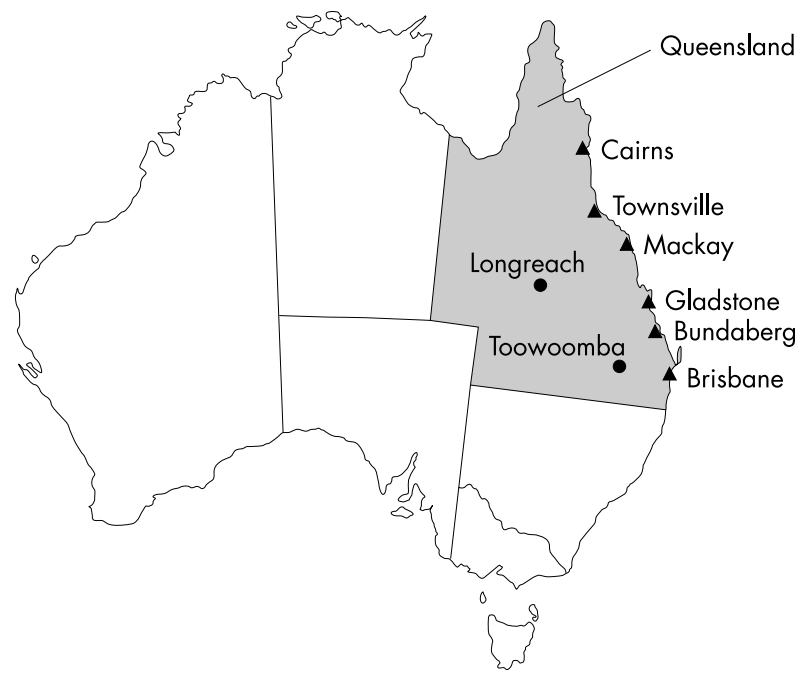

Figure 1 Location of eight cities, Queensland, Australia.

the temperate and densely populated south east to the tropical, sparsely populated Cape York Peninsula in the north. Its population was 3401232 on 30 June 1997 (fig 1)..$^{21}$

The computerised data set on the notified RRv cases in Queensland for the period 1985-96 were obtained from the Queensland Department of Health. Data provided for each notification case include a unique record reference number, state or territory code, disease code, date of onset, sex, age, aboriginality, post code of residence, and the confirmation status of the report. Climate and population data were obtained form the Australian Bureau of Meteorology and the Australian Bureau of Statistics (ABS), respectively. There are one or more meteorological stations in each study town in Queensland. For each town, the one with the longest history of meteorological recordings was chosen. The staff in these meteorological stations observed and recorded the different climatic variables every day according to the standardisation of the World Meteorological Organisation. The information is reported to the Australian Bureau of Meteorology regularly. Relevant population data were from the population census and the prediction on the basis of census by the ABS. The quality of the ABS data is highly regarded. Data on the sea tides along the coastal regions were obtained from the Queensland Department of Transport. Climate data comprised monthly maximum and minimum temperature $\left({ }^{\circ} \mathrm{C}\right)$, monthly rainfall $(\mathrm{mm})$, relative humidity at $9 \mathrm{am} / 3 \mathrm{pm} \mathrm{( \% ),} \mathrm{and} \mathrm{high}$ tidal levels $(\mathrm{cm})$. Sea level was regarded as a "climate" variable in this study because of its relevance to climate change. The frequencies of missing data were low (less than $1 \%$ ), and therefore their effect on the study findings is likely to be relatively small.

To determine whether climate variation was associated with RRv transmission, the function of cross correlations was used to compute a series of correlations between climate variables and the incidence of RRv disease over a range of time lags. ${ }^{22}{ }^{23}$ As there were correlations between the incidence of the disease and the localities of notification of the disease, the localities where the cases were notified were treated as an independent dummy variable. Because the pattern of RRv transmission appeared to differ in coastline and inland cities, the relation between climate variability and the incidence of RRv was analysed separately for these two areas. Additionally, interaction between localities and climate variables was tested after the data for coastline and inland cities were combined.

Time series Poisson regression models were performed to adjust for the autocorrelations of monthly incidence rates of $\mathrm{RRv}$ and the effects of confounding factors. Interactions between location and climate variability in the transmission of
RRv disease were also tested in the models. ${ }^{24}$ To consider the impacts of seasonality and secular change on the RRv transmission, "seasonality" was coded as a category variable and "year" when case was notified was treated as an independent dummy variable. These newly created variables were taken into account in the regression analyses as putative confounding factors, together with other independent variables, as indicated in conventional estimation methods. The population size was adjusted for by including an offset term in the Poisson model. All analyses were performed using the Statistical Analysis System software. ${ }^{25}$

\section{RESULTS}

Figures 2 and 3 show the monthly incidence rates of the RRv infection in eight cities in Queensland between 1985 and 1996. The pattern of the RRv infection appeared to differ in the coastline and inland region. Among eight cities studied, the ratios of male to female cases varied between 1.00 and 1.28. Sixty two per cent of cases were found in the age range 20-49 years.

Table 1 provides descriptive information about monthly incidence of RRv infection and climatic variables. Compared with the monthly mean incidence of $R R v$ in the coastal districts, incidence of the disease in the inland districts was lower over the same period. The monthly mean minimum temperatures and monthly total amount of precipitation were significantly higher in the coastal districts than that in the inland districts over the study period.

The results of the cross correlations show that most climate variables were significantly associated with the incidence of RRv, particularly for the cities along the coastline. The monthly incidence of $R R v$ was significantly associated with rainfall, minimum temperature, and relative humidity at $9 \mathrm{am} / 3 \mathrm{pm}$ at a lag of two months, maximum temperature at a lag of one month, and high tide in the current month at the coastline (table 2); and with relative humidity at 9 am and rainfall at a lag of two months in inland cities (table 3 ).

The time series Poisson regressive models show that, after adjustment for seasonality, the time when the case was notified and population sizes, rainfall $(\beta=0.001,95 \%$ confidence interval $(95 \% \mathrm{CI}) 0.0008$ to $0.0012, \mathrm{p}<0.0001)$, maximum temperature $(\beta=0.1471,95 \%$ CI 0.1279 to 0.1664 , $\mathrm{p}<0.0001)$, minimum temperature $(\beta=0.0436,95 \%$ CI 0.0267 to $0.0606, p<0.0001)$, relative humidity $(\beta=0.0252$, $95 \%$ CI 0.0186 to $0.0317, \mathrm{p}<0.0001)$, and high tide $(\beta=0.0004,95 \%$ CI 0.0008 to $0.00001, p<0.0001)$ appeared to have played positive significant roles in transmission of RRv disease in the coastline region, while rainfall ( $\beta=0.0015,95 \%$ CI 0.0002 to $0.0028, \mathrm{p}<0.0001)$ and relative humidity $(\beta=0.0048,95 \%$ CI 0.0425 to $0.0612, p<0.0001)$ seemed to have exhibited some impact in the inland region (table 4 ).

Poisson regression models were further performed to examine the interactions between locality and climate variability in the RRv transmission after the data from coastline and inland region were combined. The results of analyses indicate that maximum temperature seemed to exhibit greater effects on RRv in coastline than inland areas $\left(\beta_{\text {coastline }}=0.1470\right.$, $95 \%$ CI 0.1275 to $0.1666 ; \beta_{\text {inland }}=-0.0062,95 \%$ CI -0.0597 to $0.0472 ; p=0.0078$ ). Minimum temperature seemed to affect the RRv transmission inland more than at the coastline $\left(\beta_{\text {coastline }}=0.0438,95 \%\right.$ CI 0.0263 to $0.0612 ; \beta_{\text {inland }}=-0.0720$, $95 \% \mathrm{CI}-0.1302$ to $0.0137 ; \mathrm{p}=0.0001$ ). Relate humidity at 3 pm seemed to exhibit greater effects on RRv inland than at the coastline $\left(\beta_{\text {coastline }}=-0.0002,95 \%\right.$ CI 0.0082 to $0.0077 ; \beta_{\text {inland }}=$ $0.0528,95 \%$ CI 0.0373 to $0.0686 ; \mathrm{p}=0.0274$ ).

\section{DISCUSSION}

The results of this study indicate that climate variability has played a significant role in the transmission of RRV in Queensland, Australia. However, the relative importance of 
Responses of Ross River virus to climate variability

741
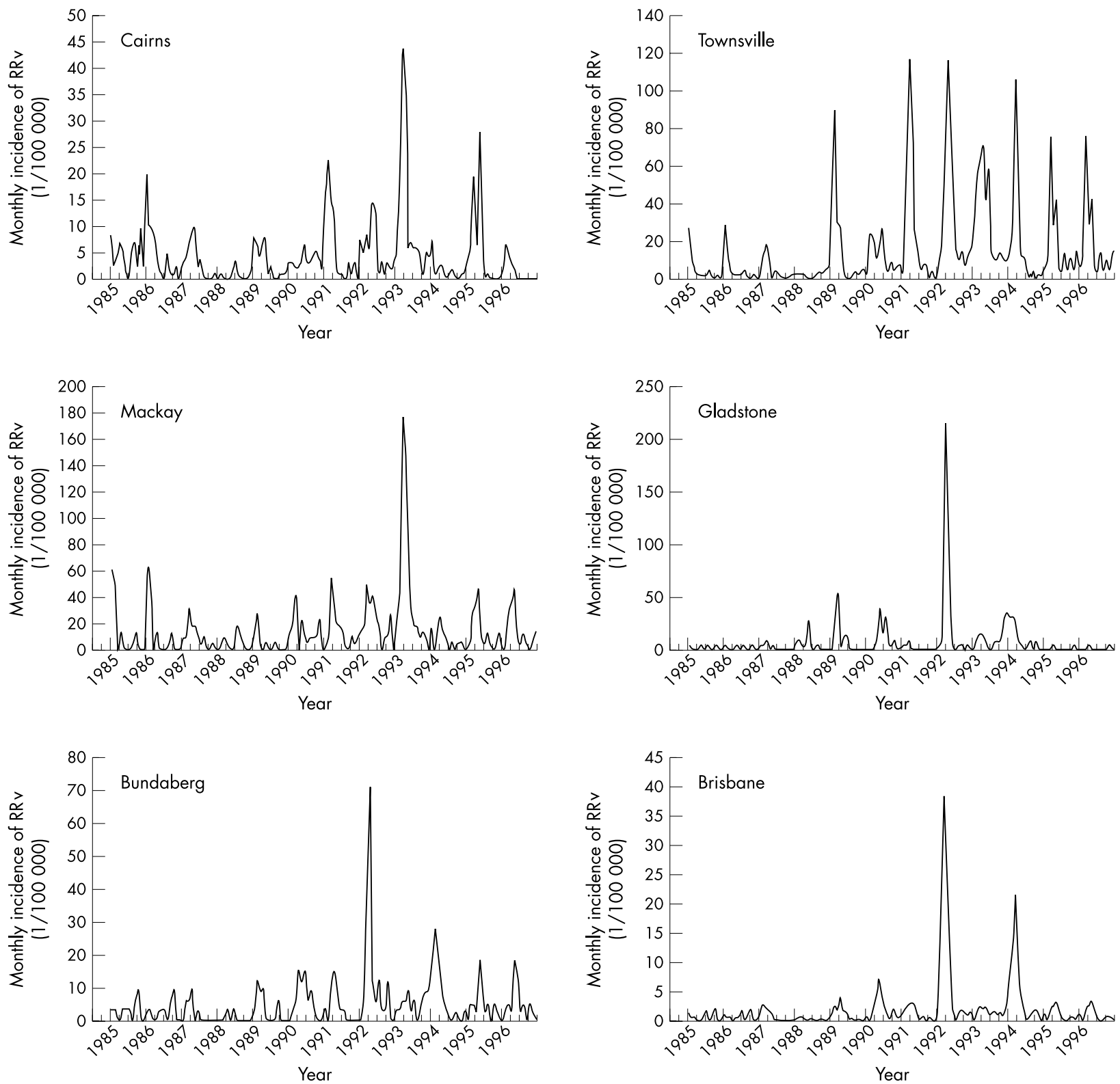

Figure 2 Monthly incidence rates of Ross River virus in coastline cities between 1985 and 1996.

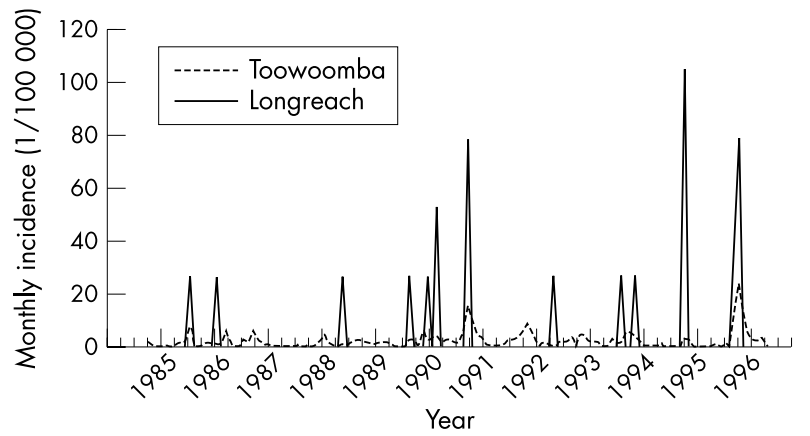

Figure 3 Monthly incidence rates of Ross River virus in inland cities between 1985 and 1996 .

these climatic factors (for example, temperature, rainfall, relafive humidity, and sea level) in the transmission of Rev varied with geographic area. There appeared to be different responses of RR to climate variability between coastline and inland cit- iss. It may be that discrete transmission cycles of RR occur in different mosquito vector species in distinct geographical regions, and may be further complicated by the involvement of different strains of virus. Moreover, cycle may also be related to the numbers of susceptible people, such as migration to endemic areas, spreading of development into mosquito breading habitats, and/or increasing susceptibility as the level of immunity declines.

The strengths of this study are: (1) to our knowledge, it is the first study to look at the response of disease to climate variability between coastline and inland cities; (2) a large scale data linkage analysis of the relation between climate variable and $\mathrm{RRv}$ was conducted, and various sources of data were used; and (3) the sophisticated statistical process demanded for time series data (for example, cross correlations and time series Poisson regression) was used.

The limitations of this study should also be acknowledged. Firstly, the quality of surveillance data is not as good as that collected for specific studies. Secondly, the ecology of RR is complex. ${ }^{11}$ There are many factors, including virus, vector, host, or environmental variations, that are involved in the

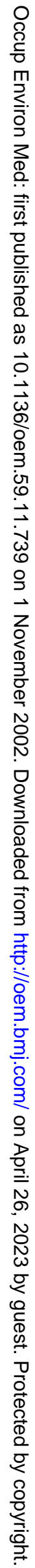

www.occenvmed.com 
Table 1 Summarised statistics for monthly incidence of RRv infection and meteorological variables in Queensland, 1985-96

\begin{tabular}{|c|c|c|c|c|c|c|c|c|}
\hline & \multicolumn{4}{|c|}{ Coastline } & \multicolumn{4}{|l|}{ Inland } \\
\hline & Mean & SD & Minimum & Maximum & Mean & SD & Minimum & Maximum \\
\hline Incidence $(1 / 100000)^{*}$ & $6.62 \dagger$ & $3.80 \ddagger$ & 0 & 149.71 & $3.72 \dagger$ & $2.14 \ddagger$ & 0 & 104.38 \\
\hline $\operatorname{MaxT}\left({ }^{\circ} \mathrm{C}\right)^{*}$ & 27.45 & 3.13 & 19 & 34.30 & 26.82 & 5.66 & 14.50 & 39.90 \\
\hline $\operatorname{MinT}\left({ }^{\circ} \mathrm{C}\right)^{* *}$ & 18.20 & 3.46 & 8.90 & 25.40 & 14.14 & 5.36 & 4.70 & 24.90 \\
\hline Rainfall $(\mathrm{mm})$ * * & $40.74 \dagger$ & $4.90 \ddagger$ & 0 & 1310.60 & $37.15 \dagger$ & $4.79 \ddagger$ & 0 & 519.60 \\
\hline $\operatorname{Rh9am}(\%) * *$ & 68.93 & 7.61 & 45.00 & 89.00 & 52.11 & 12.73 & 23.00 & 89.00 \\
\hline $\operatorname{Rh} 3 p m(\%) * *$ & 58.33 & 8.82 & 18.00 & 80.00 & 41.15 & 13.92 & 12.00 & 76.00 \\
\hline $\mathrm{HT}(\mathrm{cm})$ & 302.35 & 93.58 & 180.81 & 512.33 & $\S$ & $\S$ & & \\
\hline
\end{tabular}

MaxT, maximum temperature; MinT, minimum temperature; RH9am, relative humidity at $9 \mathrm{am} ; \mathrm{Rh} 3 \mathrm{pm}$, relative humidity at $3 \mathrm{pm} ; \mathrm{HT}$, high tide. ${ }^{*}$ Significant at $p \leqslant 0.05$ ( 2 tailed); ${ }^{* * *}$ significant at $p \leqslant 0.01$ ( 2 tailed).

$\dagger$ †eometric means of incidence of disease and rainfall; łgeometric standard deviation; §data unavailable.

transmission cycles of RRv. Climate variation, virus strain, mosquito population densities and survival, human behaviour, population immunity, and housing characteristics, all contribute to and interact in determining the transmission cycles of RRv. However, data were unavailable on virus strain, mosquito population densities and survival, human behaviour, population immunity, and housing characteristics. The lack of data may be one of the major limitations in this large

\begin{tabular}{|c|c|c|c|c|c|c|}
\hline Coastline city & MaxT & $\operatorname{MinT}$ & Rainfall & RH9am & $\mathrm{RH} 3 \mathrm{pm}$ & HT \\
\hline \multicolumn{7}{|l|}{ Cairns } \\
\hline $\operatorname{Lag} 0$ & 0.115 & 0.014 & $0.163^{*}$ & 0.070 & 0.031 & $0.218^{*}$ \\
\hline Lag 1 & 0.206 * & 0.035 & -0.028 & 0.015 & 0.030 & 0.030 \\
\hline Lag 2 & 0.017 & 0.029 & $0.177^{\star}$ & 0.123 & $0.155^{\star}$ & $0.227^{*}$ \\
\hline $\operatorname{Lag} 3$ & 0.116 & 0.025 & $0.232^{*}$ & 0.128 & 0.136 & $-0.164^{*}$ \\
\hline Lag 4 & $0.176^{*}$ & 0.062 & -0.150 & $-0.185^{*}$ & -0.098 & $-0.153^{*}$ \\
\hline \multirow{2}{*}{\multicolumn{7}{|c|}{ Townsville }} \\
\hline & & & & & & \\
\hline $\operatorname{Lag} 0$ & 0.070 & 0.050 & $-0.174^{*}$ & $-0.219^{*}$ & -0.124 & $0.306^{*}$ \\
\hline Lag 1 & -0.023 & 0.106 & 0.076 & 0.129 & 0.147 & $0.224^{*}$ \\
\hline Lag 2 & $0.161^{*}$ & $0.227^{*}$ & $0.427^{*}$ & $0.244^{*}$ & $0.293^{*}$ & 0.134 \\
\hline Lag 3 & 0.071 & -0.093 & 0.033 & 0.088 & 0.034 & -0.015 \\
\hline $\operatorname{lag} 4$ & 0.126 & 0.035 & -0.033 & -0.016 & -0.041 & $-0.159^{*}$ \\
\hline \multicolumn{6}{|l|}{ Mackay } & -0.079 \\
\hline $\operatorname{Lag} 0$ & 0.096 & 0.085 & -0.148 & -0.099 & 0.054 & 0.040 \\
\hline Lag 1 & $0.254^{*}$ & 0.114 & 0.000 & -0.031 & 0.065 & $0.166^{*}$ \\
\hline Lag 2 & -0.001 & $0.178^{*}$ & 0.128 & 0.095 & 0.076 & -0.070 \\
\hline $\operatorname{Lag} 3$ & 0.102 & 0.105 & $0.195^{*}$ & 0.029 & 0.055 & -0.074 \\
\hline Lag 4 & 0.134 & 0.127 & -0.114 & -0.122 & -0.116 & -0.001 \\
\hline $\operatorname{Lag} 5$ & 0.103 & -0.019 & -0.081 & $0.185^{*}$ & -0.151 & -0.012 \\
\hline \multicolumn{7}{|l|}{ Gladstone } \\
\hline $\operatorname{Lag} 0$ & 0.050 & 0.084 & -0.063 & 0.116 & 0.095 & 0.110 \\
\hline Lag 1 & $0.157^{*}$ & 0.137 & -0.124 & -0.046 & -0.111 & 0.091 \\
\hline Lag 2 & 0.151 & 0.118 & -0.076 & -0.002 & 0.003 & $-0.213^{*}$ \\
\hline $\operatorname{Lag} 3$ & 0.032 & 0.022 & 0.119 & 0.008 & -0.020 & -0.108 \\
\hline $\operatorname{lag} 4$ & 0.022 & 0.048 & -0.015 & 0.076 & 0.090 & 0.106 \\
\hline Lag 5 & -0.086 & -0.062 & -0.057 & -0.096 & -0.022 & -0.003 \\
\hline \multicolumn{7}{|l|}{ Bundaberg } \\
\hline $\operatorname{Lag} 0$ & 0.046 & 0.061 & -0.147 & 0.016 & 0.073 & 0.111 \\
\hline Lag 1 & 0.129 & 0.083 & 0.148 & -0.047 & -0.026 & 0.047 \\
\hline Lag 2 & $0.160 *$ & 0.143 & 0.120 & 0.149 & 0.083 & 0.036 \\
\hline $\operatorname{Lag} 3$ & $0.173^{*}$ & $0.196^{*}$ & -0.129 & -0.014 & 0.005 & 0.112 \\
\hline Lag 4 & 0.071 & 0.113 & $0.217^{*}$ & 0.035 & 0.085 & -0.078 \\
\hline Lag 5 & 0.043 & 0.146 & -0.038 & 0.075 & 0.117 & -0.036 \\
\hline \multicolumn{7}{|l|}{ Brisbane } \\
\hline Lag 0 & -0.054 & -0.186 & 0.081 & 0.087 & 0.065 & $0.188^{*}$ \\
\hline $\operatorname{Lag} 1$ & 0.140 & 0.060 & 0.047 & 0.058 & 0.068 & -0.137 \\
\hline Lag 2 & 0.064 & $0.156^{*}$ & $0.173^{*}$ & 0.060 & 0.075 & 0.111 \\
\hline Lag 3 & $0.193 *$ & 0.136 & 0.012 & 0.019 & 0.077 & 0.001 \\
\hline Lag 4 & $0.159 *$ & 0.098 & 0.101 & 0.106 & 0.055 & 0.043 \\
\hline $\operatorname{lag} 5$ & 0.113 & -0.022 & $-0.154^{*}$ & $-0.160^{*}$ & -0.090 & -0.105 \\
\hline \multicolumn{7}{|l|}{ Total } \\
\hline $\operatorname{Lag} 0$ & 0.055 & 0.048 & -0.038 & -0.004 & 0.017 & $0.110^{*}$ \\
\hline Lag 1 & $0.117^{*}$ & $0.085^{*}$ & 0.006 & 0.005 & -0.017 & 0.073 \\
\hline Lag 2 & $0.099 *$ & $0.111^{*}$ & $0.119^{*}$ & $0.075^{*}$ & $0.079 *$ & -0.054 \\
\hline $\operatorname{Lag} 3$ & 0.058 & 0.027 & 0.072 & 0.037 & 0.023 & -0.040 \\
\hline Lag 4 & 0.069 & 0.050 & -0.033 & -0.009 & 0.010 & -0.004 \\
\hline Lag 5 & 0.020 & 0.023 & -0.073 & $-0.069 *$ & -0.050 & -0.012 \\
\hline
\end{tabular}


Table 3 Cross correlation coefficients between climate variables and incidence of Ross River virus in inland region, Queensland

\begin{tabular}{llllll}
\hline Inland city & MaxT & MinT & Rainfall & RH9am & RH3pm \\
\hline Toowoomba & & & & & \\
Lag 0 & 0.078 & 0.044 & $-0.197^{*}$ & -0.061 & -0.119 \\
Lag 1 & 0.110 & $0.193^{*}$ & 0.000 & -0.102 & $0.156^{*}$ \\
Lag 2 & 0.084 & 0.146 & -0.031 & 0.083 & 0.113 \\
Lag 3 & $0.166^{*}$ & $0.187^{*}$ & $0.262^{*}$ & 0.045 & 0.031 \\
Lag 4 & $0.159^{*}$ & $0.152^{*}$ & -0.003 & 0.052 & -0.013 \\
Lag 5 & 0.160 & 0.078 & 0.029 & -0.068 & $-0.162^{*}$ \\
& & & & & \\
Longreach & & & & & \\
Lag 0 & 0.096 & 0.078 & $-0.226^{*}$ & -0.144 & -0.089 \\
Lag 1 & 0.074 & 0.024 & $0.185^{*}$ & $0.185^{*}$ & 0.067 \\
Lag 2 & 0.021 & 0.017 & $0.221^{*}$ & $0.182^{*}$ & 0.107 \\
Lag 3 & 0.090 & 0.082 & $-0.245^{*}$ & -0.139 & -0.055 \\
Lag 4 & -0.039 & 0.033 & 0.096 & -0.034 & -0.071 \\
Lag 5 & 0.132 & 0.039 & 0.029 & -0.025 & 0.039 \\
& & & & & \\
Total & & & & & \\
Lag 0 & 0.083 & 0.067 & $-0.121^{*}$ & $-0.113^{*}$ & -0.073 \\
Lag 1 & -0.051 & 0.033 & 0.096 & $0.130^{*}$ & 0.061 \\
Lag 2 & 0.023 & 0.025 & $0.139^{*}$ & $0.143^{*}$ & 0.085 \\
Lag 3 & 0.085 & 0.080 & -0.099 & -0.101 & 0.036 \\
Lag 4 & -0.020 & 0.038 & 0.049 & -0.021 & -0.051 \\
Lag 5 & 0.118 & 0.038 & 0.018 & -0.024 & 0.014 \\
\hline
\end{tabular}

MaxT, maximum temperature; MinT, minimum temperature; $\mathrm{RH} 9 \mathrm{am}$, relative humidity at $9 \mathrm{am} ; \mathrm{Rh} 3 \mathrm{pm}$, relative humidity at $3 \mathrm{pm}$. Lagx $=$ the lagged months.

*Significant at the 0.05 level (2 tailed).

scale assessment of the relation between climate variability and RRv transmission. Further research on the ecology of RRv transmission and interaction between biological and environmental factors is clearly warranted.

Despite these limitations, our data support the hypotheses that climate variation plays an important role in the transmission of RRv. Considerable evidence has accrued to show that precipitation is an important factor in the transmission of RRV in many parts of Australia. All mosquitoes have aquatic larval and pupal stages and therefore require water for breeding. ${ }^{11}{ }^{12}$ It is precipitation that determines the presence or absence of breeding sites. ${ }^{10}$ Rainfall events and subsequent floods can lead to outbreaks of arboviral disease, largely by enabling breeding of vector mosquitoes. ${ }^{12}$ In general, epidemic activity of arbovirus is more often observed in temperate areas with heavy rainfall, flooding, or high tides, whereas in tropical Australia transmission occurs throughout the year. ${ }^{26}$ Nevertheless, distinct epidemics do occur in northern Australia, especially associated with heavy monsoonal rainfalls. More frequent, lighter rains may replenish exiting breeding sites and maintain higher levels of humidity, which assists in dispersal and survival of adult mosquitoes.

Changes in climate and the environment may influence the abundance and distribution of vectors and intermediate hosts. ${ }^{10}{ }^{11}$ Warmer temperatures may allow vectors to survive winters that normally would have limited their populations and to reach maturity much faster than lower temperatures. ${ }^{11}$ For example, within the temperature range that a mosquito species can breed, rearing of larvae at high temperature has a dramatic effect on length and efficiency of the extrinsic incubation periods (EIPs) of arboviruses in their vectors. The EIPs are inversely related to the temperature of incubation, within the temperature ranges that allow virus replication to occur. In other words, mosquitos exposed to higher temperatures after ingestion of virus become "infectious" more rapidly than mosquitos of the same species exposed to lower temperatures. ${ }^{10}$ Transmission of an arbovirus may therefore be enhanced under warmer conditions because more vector mosquitoes become infectious within their life span.

High tides and rise in sea level have been implicated as important precursors of outbreaks of Rrv. ${ }^{27}{ }^{28}$ Tidal inundation of saltmarshes is a major source of water for breeding of the important arbovirus vectors Aedes vigilas and $A$ amptorhynchus. Adult females of both species lay their eggs on soil, mud substrate, and the plants around the margins of their breeding sites. The eggs hatch when high tides subsequently inundate sites. Large populations of adult mosquitoes can emerge as little as eight days after a series of spring tides. ${ }^{11}$ There is good evidence that a rise in sea level may contribute to a major outbreak of RRv. For example, in an outbreak of RRv in southwestern Australia during the summer of 1988-89, a rise in sea level of $5.5 \mathrm{~cm}$ (above the long term mean), exacerbated by a pattern of strong north and southwesterly winds, led to more frequent and widespread inundation of coastal saltmarshes in the region than is normally recorded. This subsequently increased the populations of A camptorhynchus mosquitoes and as a result, an outbreak of RRv infection occurred.$^{26}$ The results of this study corroborate the previous findings, indicating that sea level is an important factor in the transmission of RRv in the coastal region.

Relative humidity influences longevity, mating, dispersal, feeding behaviour, and oviposition of mosquitoes. ${ }^{11}$ At high humidity, mosquitoes generally survive for longer and disperse further; they have a greater chance of feeding on an infecting animal and surviving to transmit a virus to humans or other animals. Relative humidity also directly affects evaporation rates from vector breeding sites. Clearly, humidity is another factor contributing to outbreaks of RRv disease, particularly in normally arid regions. ${ }^{26}$

Disease and vector surveillance systems have played a significant role in the control of infectious disease in the past. As socioenvironmental conditions are changing, these systems need to be strengthened so that they can play active roles in the prevention of epidemic outbreaks in the future. The surveillance data should be integrated with social, biological, and environmental databases. These data can provide an important input to the development of epidemic predictive models, and these models could give forewarning and help decision makers use resources more effectively and efficiently.

Table 4 Estimated Poisson regression coefficients of climate variables on the notified cases of Ross River virus in Queensland

\begin{tabular}{|c|c|c|c|c|c|c|}
\hline & \multicolumn{3}{|l|}{ Coastline } & \multicolumn{3}{|l|}{ Inland } \\
\hline & $\beta$ & $95 \% \mathrm{Cl}$ & $\mathrm{p}$ value & $\beta$ & $95 \% \mathrm{Cl}$ & $p$ value \\
\hline Intercept & -5.985 & -6.6727 to -5.2969 & 0.0001 & -3.8135 & -4.4163 to -3.2108 & 0.0001 \\
\hline Rainfall (mm) (Lag2) & 0.0010 & 0.0008 to 0.0012 & 0.0001 & 0.0015 & 0.0002 to 0.0028 & 0.0201 \\
\hline RH9am (\%) (Lag2) & 0.0252 & 0.0186 to 0.0317 & 0.0001 & 0.0519 & 0.0425 to 0.0612 & 0.0001 \\
\hline $\operatorname{MaxT}\left({ }^{\circ} \mathrm{C}\right)(\operatorname{Lag} 1)$ & 0.1471 & 0.1279 to 0.1664 & 0.0001 & & & \\
\hline $\operatorname{MinT}\left({ }^{\circ} \mathrm{C}\right)(\operatorname{Lag} 2)$ & 0.0436 & 0.0267 to 0.0606 & 0.0001 & & & \\
\hline $\mathrm{HT}(\mathrm{cm})(\operatorname{Lag} 0)$ & 0.0004 & 0.0001 to 0.0008 & 0.0423 & & & \\
\hline
\end{tabular}

MaxT, maximum temperature; MinT, minimum temperature; RH9am, relative humidity at 9am; HT, high tide. Lagx = the lagged months. 


\section{Main messages}

- The time series data over a decade in Queensland Australia, provide an opportunity to examine the impact of climate variability on the transmission of Ross River virus.

- There was an apparent difference in the disease response to climate variability between coastline and inland regions.

- The relation between climate variability and the incidence of Ross River virus disease needs to be viewed cautiously, given the inherent limitations of ecological analysis.

\section{Policy implications}

- Our findings reveal different responses of Ross River virus disease to climate variability between coastline and inland cities.

- There was a significant interaction between locality and climate variability in the transmission of Ross River virus disease

As global warming continues, it is important to assess the potential public health consequences of such change, including its impact on the transmission of infectious diseases. The results of this study indicate that climate variability/change may influence the transmission cycles of RRv, and its impact appears to differ between coastline and inland regions. These findings may have implications in the development of public policy for mitigation and adoption of climate change.

\section{ACKNOWLEDGEMENTS}

We thank the Queensland Department of Health for providing the data on the RRv infections between 1985 and 1996. This study was partly supported by the Queensland Department of Health and Queensland University of Technology.

\section{Authors' affiliations}

S Tong, W Hu, Centre for Public Health Research, Queensland University of Technology, Kelvin Grove, Queensland 4059, Australia

\section{REFERENCES}

1 Russel RC. Vectors versus humans in Australia-Who is on top down under? An update on vector-borne disease and research on vectors in Australia. J Vect Ecol 1998;23: 1-46.

2 Mackenzie JS, Lindsay MD, Coelen RJ, et al. Arboviruses causing human disease in the Australia zoogeographic region. Arch Virol 1994:136:447-67.

3 Nimmol JR. An unusual epidemic. Med J Aust 1928;1:422-5.

4 Shope RE, Anderson SG. The virus aetiology of epidemic exanthema and polyarthritis. Med J Aust 1960;1:156-8.
5 Donerty RL, Gorman BM, Whitehead RH, et al. Studyies of epidemic polyarthritis. The significance of three group $A$ arboviruses isolated from mosquitoes in Queensland. Aust Ann Med 1964;13:322-7.

6 Curran M, Harvey B, Crerar S, et al. Australia's notifiable disease status, 1996. Commun Dis Intell 1997:21:281-307.

7 Hawkes RA, Boughton CR, Naim HM. A major outbreak of epidemic polyarthritis in New South Wales during the summer of 1983/1984. Med J Aust 1985;7:330-3.

8 Australia Department of Health and Aged Care 2000. National notifiable diseases surveillance system. http://www.health.gov.au/ public/cdi/nndss/year002.htm (cited 16 January 2001).

9 Tong S, Bi P, Parton K, et al. Climate variability and transmission of epidemic polyarthritis. Lancet 1998;351:1100.

10 Kay BH, Aaskov JG. Ross River virus (epidemic polyarthritis). In: TP Monath, ed. The arboviruses: epidemiology and ecology, Vol. IV. Boca Raton, FL: CRC Press, 1998:93-112.

11 McMichael AJ, Haines A, Slooff R. Climate changes and human health. Geneva: WHO, 1996.

12 Lindsay MD, Mackenzie JS, Condon RJ. Ross River virus outbreaks in Western Australia: epidemiological aspects and the role of environmental factors. In: Ewan CE, Bryant EA, Calvert GD, Garrick JA, eds. Health in the Greenhouse. Canberra: Australian Government Publishing Service, 1993:85-100.

13 Philip W. An ecological approach to public health intervention: Ross River virus in Australia. Environ Health Perspect 1997;4:364-6.

14 Helfenstein U. Box-Jenkins modelling of some viral infectious diseases. Stat Med 1986:5:37-47.

15 Catalano R, Serxner S. Time series designs of potential interest to epidemiologists. Am J Epidemiol 1987;126:724-31.

16 Helfenstein $U$. The use of transfer function models in epidemiology. Int $J$ Epidemiol 1991;20:808-15.

17 Bowie C, Prothero D. Finding causes of seasonal diseases using time series analysis. Int J Epidemiol 1981;10:87-92

18 Walters S, Phupinyokul M, Ayres J. Hospital admission rates for asthma and respiratory disease in the West Midlands: their relationship to air pollution levels. Thorax 1995;50:948-54.

19 Sheppard L, Levy D, Norris G, et al. Effects of ambient air pollution on nonelderly asthma hospital admissions in Seattle, Washington, 1987-1994. Epidemiology 1999;10:23-30.

20 Schouten JP, Vonk JM, de Graaf A. Short term effects of air pollution on emergency hospital admissions for respiratory disease: results of the APHEA project in two major cities in the Netherlands, 1977-89. J Epidemiol Commun Health 1996;50:S22-9.

21 Australian Bureau of Statistics. Queensland Year Book 1998. Brisbane: Watson Ferguson and Company, 1998.

22 Abraham B, Ledolter J. Statistical methods for forecasting. New York: Wiley, 1983:225-9,336-55.

23 Chatfield C. The analysis of time series: theory and practice. London: Chapman \& Hall, 1975

24 Box GEP, Jenkins GM. Time-series analysis: forecasting and control. Maidenhead: McGraw-Hill, 1970.

25 SAS Institute. SAS /STAT software changes and enhancements through release 6.12. SAS Campus Drive, NC, 1997

26 Lindsay M, Mackenzie J. Vector-borne viral diseases and climate change in the Australia region: major concerns and public health response. In: Curson P, Guest C, Jackson E, eds. Climate change and human health in the Asia-Pacific region. Canberra: Australian Medical Association and Greenpeace International, 1997:46-62.

27 McManus TJ, Russell RC, Wells PJ, et al. Further studies on the epidemiology and effects of Ross River virus in Tasmania. Arbovirus Res Aust 1992;6:68-72

28 Phillips DA, Sheridan J, Aaskov J, et al. Epidemiology of arbovirus infection in Queensland, 1989-1992. Arbovirus Res Aust $1992 ; 6: 245-8$. 